\title{
Fontes de nitrogênio, polpa de banana e ágar no desenvolvimento in vitro de plântulas de orquídea
}

\author{
Moacir Pasqual'; Milene A de Figueiredo, ${ }^{3,6}$; Juliana C de Rezende²; Aparecida G de Araújo ${ }^{4,6}$; Flávia \\ C Santos $^{3,7}$; Ester A Ferreira ${ }^{2}$; Keize P Junqueira ${ }^{5,7}$ \\ ${ }^{1}$ UFLA-DAG, C. Postal 3037; 37200-000 Lavras-MG; ${ }^{2}$ Pesquisadora EPAMIG; ${ }^{3}$ Doutoranda UFLA; ${ }^{4}$ Pós-Doutoranda UFLA; \\ ${ }^{5}$ Doutoranda UnB; ${ }^{6}$ Bolsista CAPES; ${ }^{7}$ Bolsista CNPq; mpasqual@ufla.br
}

\section{RESUMO}

Foram realizados dois experimentos com o objetivo de estudar os efeitos de fontes de nitrogênio, polpa de banana e ágar no desenvolvimento in vitro de orquídea Cattleya loddigesii. O primeiro experimento constituiu-se de $\mathrm{NH}_{4} \mathrm{NO}_{3}(0 ; 25 ; 50 ; 75$ e $100 \%$ da formulação de $\left.330 \mathrm{mg} \mathrm{L}^{-1}\right)$ e $\mathrm{KNO}_{3}(0 ; 25 ; 50$ e $100 \%$ da formulação de 380 $\left.\mathrm{mg} \mathrm{L}^{-1}\right)$ acrescidas ao meio MS. No segundo experimento, os tratamentos consistiram de concentrações de ágar $\left(0 ; 2 ; 4 ; 6\right.$ e $\left.8 \mathrm{~g} \mathrm{~L}^{-1}\right)$, no meio de cultura Knudson C, acrescido de polpa de banana nanica ( 0 ; 50; $100 ; 150$ e $200 \mathrm{~g} \mathrm{~L}^{-1}$ ) em todas as combinações possíveis. Após a inoculação as culturas foram mantidas em sala de crescimento com irradiância em torno de $35 \mu \mathrm{mol} \mathrm{m} \mathrm{m}^{-2} \mathrm{~s}^{-1}$, temperatura de $25 \pm 1^{\circ} \mathrm{C}$ e fotoperíodo de 16 horas, por 90 dias. Com base no peso da matéria fresca das plântulas, número de raízes, comprimento da parte aérea e comprimento da maior raiz, a adição de 17,5 a 41,16\% da formulação original de $\mathrm{NH}_{4} \mathrm{NO}_{3}$ ao meio MS proporcionou melhor desenvolvimento in vitro em plântulas de Cattleya loddigesii. Maior número de folhas foi obtido com a adição ao meio MS de $100 \%$ da formulação original de $\mathrm{NH}_{4} \mathrm{NO}_{3}$ e $50 \%$ de $\mathrm{KNO}_{3}$. A multiplicação in vitro de plântulas de orquídea Cattleya loddigesii é viável em meio Knudson C líquido com a utilização de $128,42 \mathrm{~g} \mathrm{~L}^{-1}$ de polpa de banana nanica.

Palavras-chave: Cattleya loddigesii, Orchidaceae, cultura de tecidos, meios de cultura.

\begin{abstract}
Nitrogen sources, banana pulp and agar in the orchid seedlings in vitro development

Two experiments were carried out in order to evaluate the effects of nitrogen sources, banana pulp and agar on Cattleya loddigesii seedlings development in vitro. In the first experiment were tested $\mathrm{NH}_{4} \mathrm{NO}_{3}$ at $0 ; 25 ; 50 ; 75$ and $100 \%\left(330 \mathrm{mg} \mathrm{L}^{-1}\right.$ formulation) and $\mathrm{KNO}_{3} 0 ; 25 ; 50$ and $100 \%$ (380 mg L $\mathrm{m}^{-1}$ formulation) added to MS medium. The second experiment consisted of different agar concentrations $\left(0 ; 2 ; 4 ; 6\right.$ and $\left.8 \mathrm{~g} \mathrm{~L}^{-1}\right)$, banana nanica pulp $(0 ; 50 ; 100$; 150 and $\left.200 \mathrm{~g} \mathrm{~L}^{-1}\right)$ in all the possible combinations added to Knudson $\mathrm{C}$ medium. After inoculation the plantlets were maintained in growth room with irradiancy around $35 \mu \mathrm{mol} \mathrm{m} \mathrm{m}^{-2} \mathrm{~s}^{-1}, 25 \pm 1^{\circ} \mathrm{C}$ temperature and 16-hour photoperiod for 90 days. The $\mathrm{NH}_{4} \mathrm{NO}_{3}$ formulation added to culture medium at 17,5 to $41,16 \%$ provides best development of Cattleya loddigesii plantlets based on plantlets fresh mass, number of roots, largest root length and aerial part length. Larger number of leaves was obtained at $100 \%$ of the original formulation of $\mathrm{NH}_{4} \mathrm{NO}_{3}$ and $50 \%$ of $\mathrm{KNO}_{3}$ in MS medium The best results for in vitro multiplication of Cattleya loddigesii orchid seedlings occurred in liquid Knudson C medium with $128,42 \mathrm{~g} \mathrm{~L}^{-1}$ banana nanica pulp.
\end{abstract}

Keywords: Cattleya loddigesii, Orchidaceae, tissue culture, culture media.

(Recebido para publicação em 18 de janeiro de 2008; aceito em 6 de abril de 2009)

(Received in January 18, 2008; accepted in April 6, 2009)

\begin{abstract}
A cultura de tecidos em orquídeas constitui técnica bastante relevante dos pontos de vista comercial e ecológico. As plantas produzidas desta forma são altamente interessantes para programas de reintrodução de espécies nativas em áreas de preservação ambiental (Araújo, 2007). A cultura assimbiótica resulta em maiores percentuais de germinação em comparação com a germinação em condições naturais, que é dependente da infecção por fungos micorrízicos simbiontes, muitas vezes espécie-específicos (Araújo, 2004). A obtenção de orquídeas a partir da semeadura in vitro é, atualmente, um processo rotineiro. No entanto, os conhecimentos sobre a melhor formulação do meio de cultura para cada espécie ainda são limitados. Um grande número de fa-
\end{abstract}

tores complexos influencia a germinação e o crescimento in vitro de orquídeas, sendo altamente dependentes do genótipo (Silva et al., 2002).

Os fatores que mais freqüentemente determinam o sucesso da micropropagação são a origem do explante e o meio nutritivo onde são cultivados. Várias mudanças de padrão foram propostas na tentativa de otimizar o crescimento in vitro. Essas modificações visam principalmente a redução ou o incremento de alguns componentes que podem promover melhor crescimento em tecidos de orquídeas (Pasqual et al., 2001).

George et al. (2008) sugerem que a adição no meio de cultura de compostos orgânicos complexos como polpa de banana pode suplementar o teor de vi- taminas, aminoácidos e reguladores de crescimento. De acordo com Arditti \& Ernst (1993), a polpa de banana madura pode intensificar o crescimento de plântulas obtidas a partir de explantes in vitro. No mesmo sentido, Torres et al. (2001) citam que essa substância pode promover diferentes efeitos no cultivo in vitro, tais como espessamento e/ou crescimento das raízes, dependendo da cultivar e da quantidade de polpa de banana utilizada.

$\mathrm{O}$ ágar tem sido muito utilizado na propagação in vitro, pela sua grande eficiência como agente geleificante, promovendo condições ideais de suporte para as plântulas no meio de cultura ( $\mathrm{Fa}-$ ria et al., 2006). Segundo Grattapaglia \& Machado (1998), há uma tendência mundial para se buscarem sistemas utilizan- 
do meio líquido, em virtude da redução do custo pela eliminação do ágar e maior agilidade na preparação do meio.

Os elementos minerais exigidos em maiores quantidades para o crescimento de plantas são incluídos nos meios nutritivos nas formas de sais inorgânicos, podendo o nitrogênio ser adicionado como componente de suplementos orgânicos (Caldas et al., 1998). O nitrogênio, juntamente com a sacarose, é o principal componente em quantidade no meio de cultura, contribuindo de forma efetiva tanto no metabolismo celular como na regulação do seu potencial osmótico (Nagao et al., 1994).

Por apresentar-se nas formas de cátion (amônio) e ânion (nitrito e nitrato), o nitrogênio difere dos demais macronutrientes (Caldas et al., 1998). Esses íons são de grande importância no controle do $\mathrm{pH}$ do meio de cultura, atuam como agente tamponante e favorecem a absorção de outros íons presentes no meio (Nagao et al., 1994).

A preocupação com a conservação dos genótipos das orquídeas nativas, ameaçadas de extinção, em decorrência da devastação acelerada dos ambientes naturais, levou à realização do presente trabalho, que objetivou estudar os efeitos de diferentes concentrações de $\mathrm{NH}_{4} \mathrm{NO}_{3}, \mathrm{KNO}_{3}$, ágar e polpa de banana nanica no desenvolvimento in vitro de plântulas de orquídea Cattleya loddigesii.

\section{MATERIAL E MÉTODOS}

Plantas adultas de Cattleya loddigesii foram coletadas previamente ao enchimento do lago da Usina Hidroelétrica do Funil, situado no Rio Grande, entre os municípios de Lavras e Perdões, em 2002. Essas plantas foram acondicionadas em vasos e permaneceram em casa de vegetação até o florescimento, em maio de 2003. Neste estágio foi feita a autofecundação das flores, as quais desenvolveram cápsulas e, cerca de nove meses depois, foram coletadas e levadas ao laboratório.

A assepsia constou de lavagem em água corrente por cinco minutos, imersão em solução de álcool $70 \%$ por um minuto e desinfestação com hipoclorito de sódio, na concentração de $1 \%$, durante
20 minutos. Em seguida, as cápsulas foram lavadas com água destilada autoclavada por três vezes. Essa operação foi realizada em câmara de fluxo laminar desinfestada com álcool $70 \%$.

Com auxílio de estilete esterilizado foi feita uma incisão na cápsula, liberando as sementes, que foram inoculadas em frascos contendo meio de cultura Knudson C (1946), acrescido de $2 \mathrm{~g} \mathrm{~L}^{-1}$ de carvão ativado e $100 \mathrm{~g} \mathrm{~L}^{-1}$ de polpa de banana nanica madura. Os frascos permaneceram em sala de crescimento com irradiância em torno de $35 \mu \mathrm{M} \mathrm{m}^{-2} \mathrm{~s}^{-}$ ${ }^{1}$, temperatura de $25 \pm 1^{\circ} \mathrm{C}$ e fotoperíodo de 16 horas, até que houvesse o desenvolvimento dos protocormos e plântulas, explantes usados para realização dos experimentos.

Experimento 1: Protocormos foram inoculados em meio MS (Murashige \& Skoog, 1962) constituído de concentrações de $\mathrm{NH}_{4} \mathrm{NO}_{3}(0 ; 25 ; 50 ; 75$ e $100 \%$ da formulação de $\left.330 \mathrm{mg} \mathrm{L}^{-1}\right)$ e de $\mathrm{KNO}_{3}(0$; 25; 50 e $100 \%$ da formulação de $380 \mathrm{mg}$ $\mathrm{L}^{-1}$ ) em todas as combinações possíveis, suplementado de sacarose $\left(30 \mathrm{~g} \mathrm{~L}^{-1}\right)$. Utilizou-se o delineamento experimental inteiramente casualizado, em esquema fatorial 4 x 5, com 5 repetições e 4 protocormos por frasco. Foram analisados o número de folhas e de raízes, comprimento da maior raiz e da parte aérea e peso da matéria fresca da plântula.

Experimento 2: Plântulas, com 1 a $1,5 \mathrm{~cm}$ de comprimento e contendo raízes pequenas $( \pm 0,5 \mathrm{~cm})$, foram inoculadas em meio de cultura Knudson C, acrescido de ágar $\left(0 ; 2 ; 4 ; 6\right.$ e $\left.8 \mathrm{~g} \mathrm{~L}^{-1}\right)$ e de polpa de banana nanica madura $(0 ; 50$; $100 ; 150$ e $200 \mathrm{~g} \mathrm{~L}^{-1}$ ) em todas as combinações possíveis, suplementado de sacarose $\left(20 \mathrm{~g} \mathrm{~L}^{-1}\right)$ e carvão ativado $(2 \mathrm{~g}$ $\left.\mathrm{L}^{-1}\right)$. Utilizou-se o delineamento experimental inteiramente casualizado, em esquema fatorial 5 x 5, com 4 repetições e 4 plântulas por frasco. As variáveis analisadas foram número de brotos, altura da parte aérea, massa seca da parte aérea, comprimento de raízes e massa seca de raízes.

Em ambos os experimentos, os meios tiveram o $\mathrm{pH}$ ajustado para 5,8 $\pm 0,1$, sendo $60 \mathrm{~mL}$ vertidos em frasco de vidro com capacidade de $250 \mathrm{~cm}^{3}$, antes do processo de autoclavagem a $121^{\circ} \mathrm{Ce} 1,1$ atm por 20 minutos. Após o resfriamento, os frascos foram levados à câmara de fluxo laminar, onde foi feita a inoculação dos explantes, sob condições assépticas. Após inoculação, os frascos foram mantidos em sala de crescimento com irradiância em torno de $35 \mu \mathrm{mol} \mathrm{m}{ }^{-2}$ $\mathrm{s}^{-1}$, temperatura de $25 \pm 1^{\circ} \mathrm{C}$ e fotoperíodo de 16 horas, por 90 dias.

A análise de variância foi realizada utilizando o procedimento GLM do “software” estatístico SAS ${ }^{\circledR}$ (SAS, 1990) por meio do método dos quadrados mínimos ponderados pelo inverso das variâncias de cada tratamento, dada a heterogeneidade das variâncias. Devido à perda de unidades experimentais, algumas combinações dos fatores não puderam ser estudadas.

\section{RESULTADOS E DISCUSSÃO}

Experimento 1: A interação entre os fatores mostrou significância apenas para a variável número de folhas. Somente as concentrações de $\mathrm{NH}_{4} \mathrm{NO}_{3}$ influenciaram significativamente as demais variáveis analisadas (Figuras 1 e 2).

A concentração de $21,31 \%$ de $\mathrm{NH}_{4} \mathrm{NO}_{3}$ apresenta-se como quantidade ideal para peso da matéria fresca das plântulas (Figura 1A), registrando-se decréscimo a partir desse ponto. Este resultado, de certa forma, difere dos obtidos por Araújo et al. (2005), relatando que o incremento das concentrações de $\mathrm{NH}_{4} \mathrm{NO}_{3}$ e $\mathrm{KNO}_{3}$ promoveu aumento no peso da matéria fresca das plântulas de Cattleya nobilior, tendo sido o maior peso obtido com adição de $100 \%$ de $\mathrm{NH}_{4} \mathrm{NO}_{3}$ e $\mathrm{KNO}_{3}$ em meio Knudson $\mathrm{C}$.

Para comprimento da parte aérea (Figura 1B) a equação apresentou bom ajuste dos dados $\left(\mathrm{R}^{2}=0,83\right)$ e uma vez derivada indicou o ponto de máximo na concentração de $35 \%$ de $\mathrm{NH}_{4} \mathrm{NO}_{3}$, havendo, a partir daí, decréscimo dos valores. Resultados similares foram obtidos por Araújo et al. (2005), que recomendam o incremento de $50 \%$ de $\mathrm{NH}_{4} \mathrm{NO}_{3}$ e $\mathrm{KNO}_{3}$ no meio de cultura para comprimento da parte aérea em plântulas de Cattleya leopoldii.

Pode-se inferir o efeito estimulante do número de raízes até a concentração de $41,16 \%$ de $\mathrm{NH}_{4} \mathrm{NO}_{3}$, havendo a partir daí decréscimo dos valores (Figura 1C). Houve aumento no comprimento da 


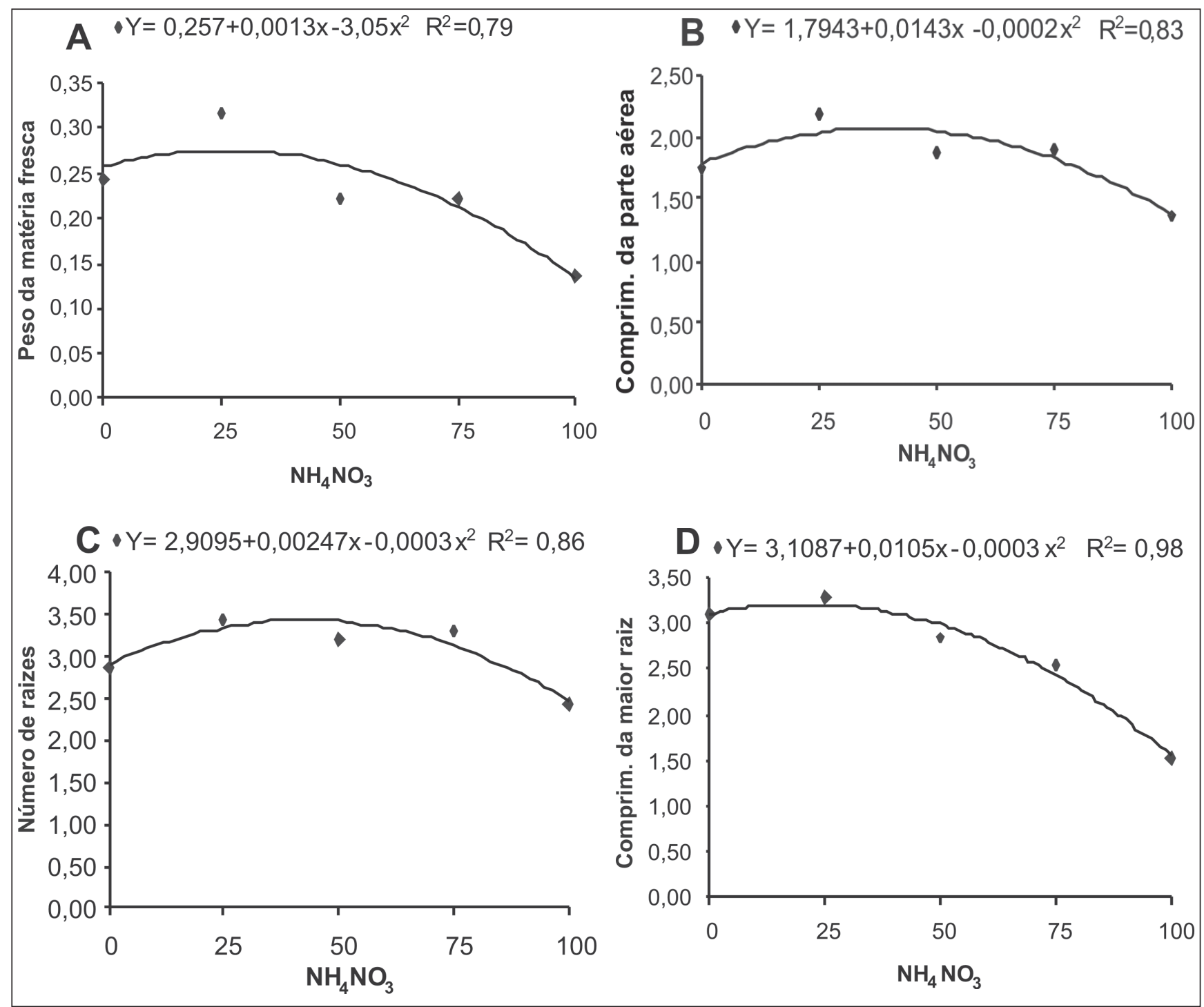

Figura 1. Peso da matéria fresca (A), comprimento da parte aérea (B), número de raízes (C)e comprimento da maior raiz em plântulas de Cattleya loddigesii em função de concentrações de $\mathrm{NH}_{4} \mathrm{NO}_{3}(\mathrm{D})$. (weight of the fresh matter (A), length of shoot (B), number of roots (C) and length of the longest root in seedlings of Cattleya loddigesii according to concentrations of $\mathrm{NH}_{4} \mathrm{NO}_{3}$ (D)). Lavras, UFLA, 2007.

maior raiz até a concentração de $17,5 \%$ de $\mathrm{NH}_{4} \mathrm{NO}_{3}$, havendo a partir daí redução da variável (Figura 1D). Araújo et al. (2005) também obtiveram resultados semelhantes, trabalhando com plântulas de Cattleya nobilior.

Todas as variáveis estudadas, exceto número de folhas, seguiram a mesma tendência, o nitrato de amônio estimulou aumento até certo ponto, tornando-se tóxico a partir do mesmo, com o aumento das concentrações, provavelmente causado pelos distúrbios nutricionais pela adição desse sal ao meio de cultura.

Após desdobramento da interação concentração de $\mathrm{NH}_{4} \mathrm{NO}_{3}$ e de $\mathrm{KNO}_{3}$ sobre a variável número de folhas, apenas a concentração de $50 \%$ de $\mathrm{KNO}_{3}$ nas

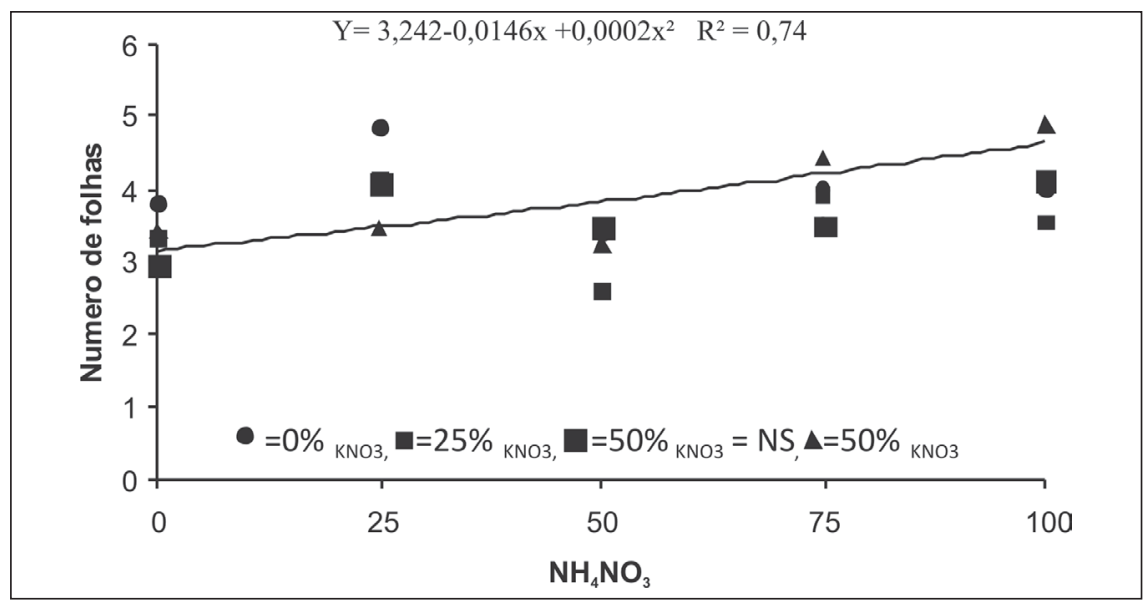

Figura 2. Número de folhas em plântulas de orquídea Cattleya loddigesii nas concentrações estudadas de $\mathrm{NH}_{4} \mathrm{NO}_{3}$ combinadas com a concentração de $50 \%$ de $\mathrm{KNO}_{3}$ (number of leaves on seedlings of Cattleya loddigesii orchid with the concentration of $\mathrm{NH}_{4} \mathrm{NO}_{3}$ combined with the level of $50 \%$ of $\mathrm{KNO}_{3}$ ). Lavras, UFLA, 2007. 

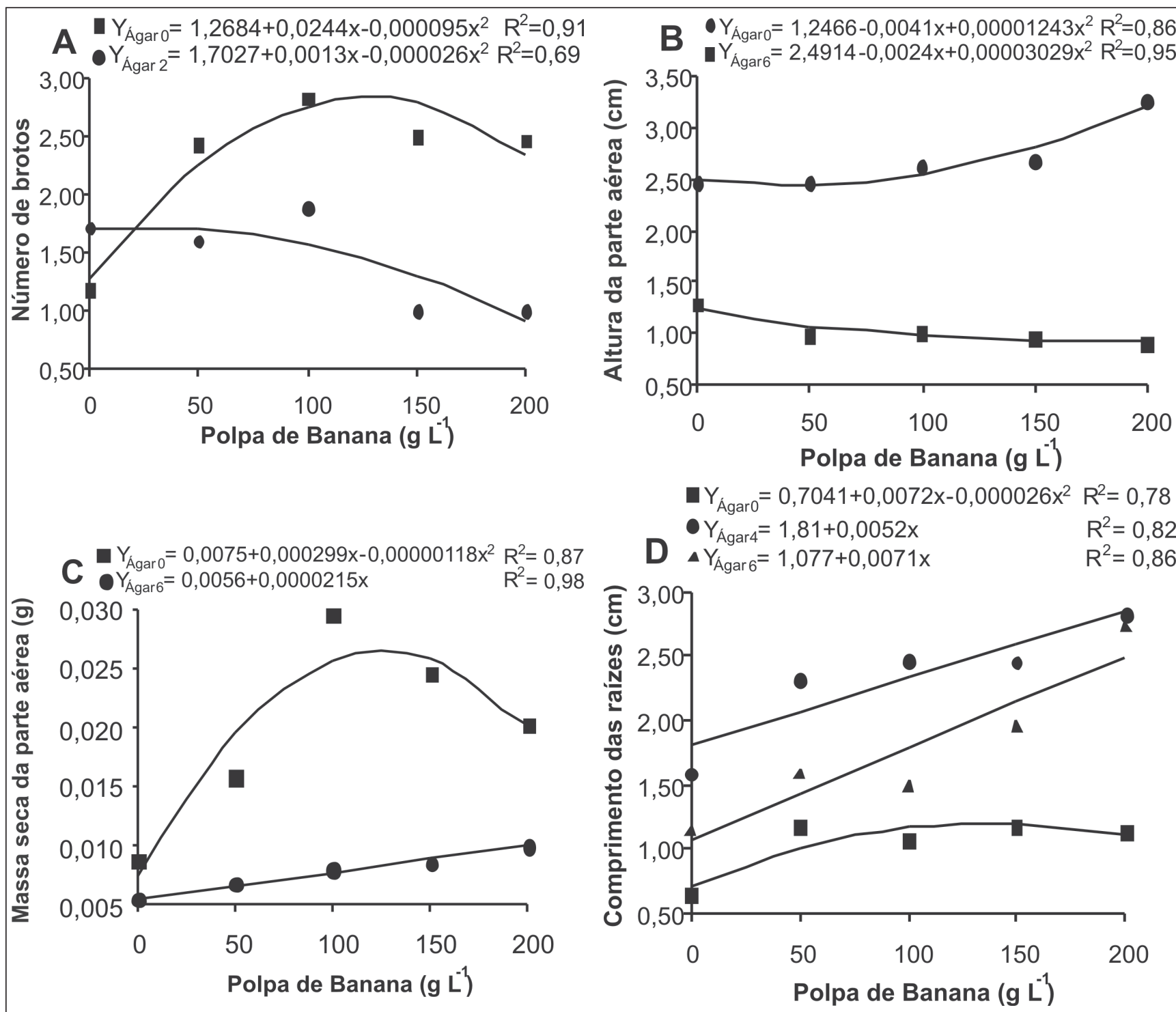

Figura 3. Número de brotos(A), altura da parte aérea (B), massa seca da parte aérea (C) e comprimento das raízes em plântulas de orquídea Cattleya loddigesii nas diferentes concentrações de ágar e polpa de banana (D) (number of shoots (A), shoot height (B), dry mass of shoot (C) and length of roots in seedlings of Cattleya loddigesii orchid in different concentrations of agar and banana pulp (D)).Lavras, UFLA, 2007.

concentrações de nitrato de amônio $\left(\mathrm{NH}_{4} \mathrm{NO}_{3}\right)$ apresentou significância (Figura 2), observando-se aumento no número de folhas com o incremento de $\mathrm{NH}_{4} \mathrm{NO}_{3}$, até a máxima concentração utilizada.

Sato et al. (2001), estudando a influência da concentração de nitrato de amônio na micropropagação da mandioca (Manihot esculenta), verificaram que o número de folhas cresceu com o aumento da concentração de $\mathrm{NH}_{4} \mathrm{NO}_{3}$, e na concentração de 41,20 mM L${ }^{-1}$ de $\mathrm{NH}_{4}^{+}$, que equivale ao dobro da concentração de nitrato de amônio utilizada no meio MS, o número de folhas foi maior (7 folhas), na presença de BAP.
Os resultados encontrados são concordantes com os de Sato et al. (2001) que afirmam que a maioria das plantas prioriza a absorção de $\mathrm{NH}_{4}^{+} \mathrm{a} \mathrm{NO}_{3}^{-}$. Além do favorecimento do $\mathrm{pH}$ do meio (aproximadamente 5,8), a assimilação do íon amônio requer uma demanda energética menor em relação à assimilação do íon nitrato (Nagao et al., 1994).

Experimento 2: Observa-se na Figura 3A que, na ausência de ágar, o aumento da concentração de polpa de banana até o limite de $128,4 \mathrm{~g} \mathrm{~L}^{-1}$ promove incremento na taxa de multiplicação, registrando-se 2,84 brotos por explante. Em concentrações superiores houve tendência de redução do número de bro- tos. Ao se utilizar $2 \mathrm{~g} \mathrm{~L}^{-1}$ de ágar, houve decréscimo no número de brotos na medida em que se aumentaram as concentrações de polpa de banana. Por outro lado, nessa concentração de ágar, verifica-se que na ausência de polpa de banana, o número de brotos é maior do que aquele observado em meio líquido.

Os resultados obtidos estão de acordo com afirmações de Arditti \& Ernst (1993), de que a adição de polpa de banana no meio de cultivo aumenta o número de brotos na propagação in vitro de plântulas de orquídeas. Concordam em parte com Silva et al. (2005), que estudando a micropropagação de orquídea Brassolaeliocattleya 'Pastoral' $\mathrm{x}$ 
Laeliocattleya 'Amber Glow', registraram que $75 \mathrm{~g} \mathrm{~L}^{-1}$ de polpa de banana promoveram a formação de maior número de brotos.

Ocorreu uma tendência de aumento no tamanho de brotos com o aumento das concentrações de polpa de banana (Figura 3B). Maior altura da parte aérea é obtida na concentração de $200 \mathrm{~g} \mathrm{~L}^{-1}$ de polpa da banana e $6 \mathrm{~g} \mathrm{~L}^{-1}$ de ágar. Nessa concentração de ágar e na ausência de polpa de banana observa-se maior altura da parte aérea das plântulas do que em meio líquido. De modo semelhante, bom crescimento in vitro de plântulas de Dendrobium nobile Lindl, em meio de cultura, com adição de $60 \mathrm{~g} \mathrm{~L}^{-1}$ de polpa de banana foi evidenciado por Song et al. (1999). A adição de polpa promove desenvolvimento da parte aérea no cultivo in vitro de orquídea, bem como emissão de brotos adventícios (Torres \& Barbosa, 2001).

Melhor resultado para massa seca da parte aérea $(0,0264 \mathrm{~g})$ é observado na ausência de ágar com 126,7 g L-1 de polpa de banana (Figura 3C), concordando com os resultados de Pasqual et al. (2008) que obtiveram maior massa seca de parte aérea de abacaxi ornamental (Ananas lucidus L.) na ausência de ágar e de reguladores de crescimento e está de acordo com Adelberg et al. (1997), reportando que o cultivo em meio líquido apresenta crescimento mais vigoroso de plântulas. A polpa de banana pode suplementar o teor de vitaminas, aminoácidos e reguladores de crescimento ao meio de cultura, promovendo aumento da massa fresca da plântula (George et al., 2008).

$\mathrm{O}$ incremento da concentração de polpa de banana, associado a $4 \mathrm{~g} \mathrm{~L}^{-1} \mathrm{de}$ ágar, promoveu aumento no comprimento das raízes das plântulas de forma linear (Figura 3D). Maior comprimento das raízes $(2,85 \mathrm{~cm})$ foi obtido na concentração de $4 \mathrm{~g} \mathrm{~L}^{-1}$ de ágar e $200 \mathrm{~g} \mathrm{~L}^{-1}$ de polpa da banana. Na ausência de ágar e polpa de banana pode-se observar o menor comprimento das raízes $(0,70 \mathrm{~cm})$. A variável massa seca das raízes também obteve melhor resultado com a utilização de $4 \mathrm{~g} \mathrm{~L}^{-1}$ de ágar e $200 \mathrm{~g} \mathrm{~L}^{-1}$ de polpa de banana (Figura 4). Essa resposta pode ser explicada pelo fato de concentrações elevadas de ágar dificultarem o contato

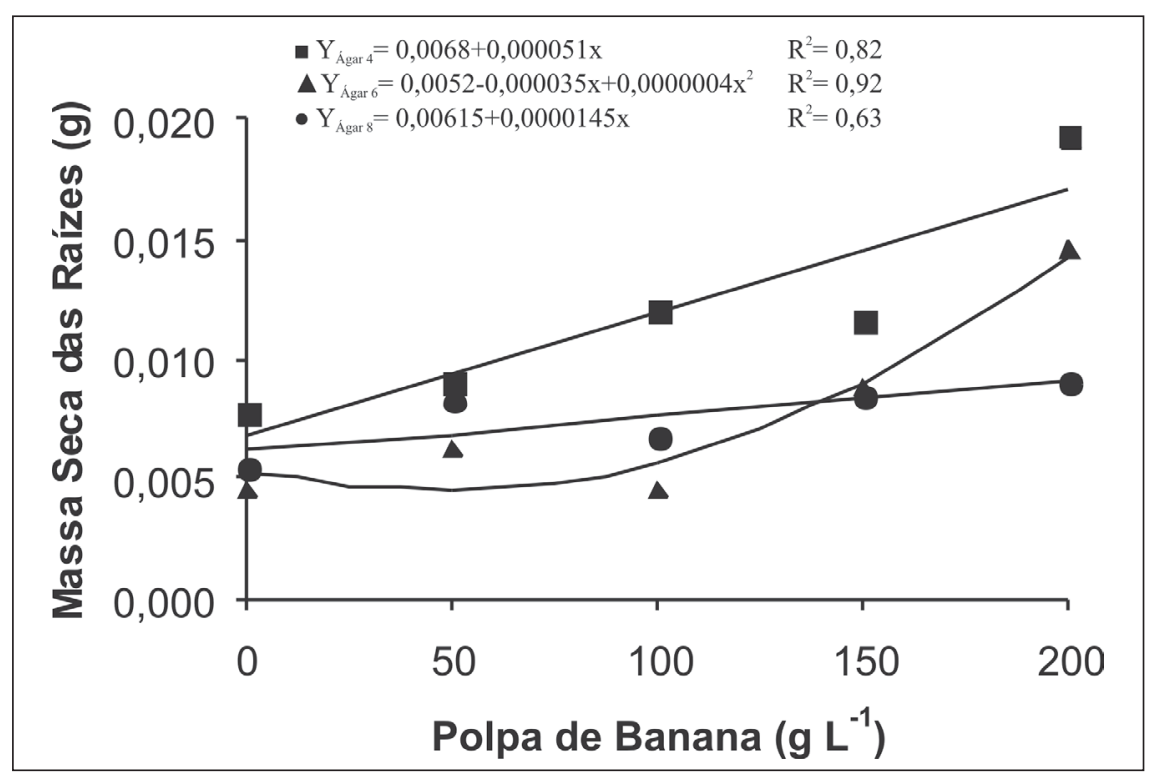

Figura 4. Massa seca das raízes em plântulas de orquídea Cattleya loddigesii cultivadas em diferentes concentrações de ágar e polpa de banana (dry mass of roots in seedlings of Cattleya loddigesii orchid grown in different concentrations of agar and banana pulp). Lavras, UFLA, 2007.

do explante com o meio, limitando a absorção de sais minerais.

De forma similar ao que ocorreu com orquídea nesse experimento, o enraizamento in vitro do abacaxi ornamental foi viável em meio MS líquido (Pasqual et al., 2008). A adição de $100 \mathrm{~g}$ $\mathrm{L}^{-1}$ de polpa de banana promoveu maior crescimento da parte aérea e da maior raiz e o aumento da massa fresca de raízes de plântulas de orquídea Cattleya loddigesii 'Grande' x Cattleya loddigesii 'Alba' (Araújo et al., 2006). Analisando o enraizamento in vitro de plântulas de Dendrobium nobile Lindl, em diferentes meios de cultura, Song et al. (1999) verificaram que a combinação Adubo Peters ${ }^{\circledR}\left(3 \mathrm{~g} \mathrm{~L}^{-1}, 20 \mathrm{~g} \mathrm{~L}^{-1}\right.$ de sacarose, 60 $\mathrm{g} \mathrm{L}^{-1}$ de polpa de banana) proporcionou maior número de raízes. O uso de meios líquidos viabiliza a absorção de nutrientes e minerais presentes no meio de cultura, favorecendo o acúmulo de matéria fresca e seca no explante.

Com base no peso da matéria fresca das plântulas, número de raízes, comprimento da parte aérea e comprimento da maior raiz, a adição de 17,5 a 41,16\% da formulação original de $\mathrm{NH}_{4} \mathrm{NO}_{3}$ ao meio MS proporciona o melhor desenvolvimento in vitro de plântulas de Cattleya loddigesii. Maior número de folhas é obtido com a adição ao meio MS de $100 \%$ da formulação original de $\mathrm{NH}_{4} \mathrm{NO}_{3}$ e $50 \%$ de $\mathrm{KNO}_{3}$.
A multiplicação in vitro de plântulas de orquídea Cattleya loddigesii é viável em meio Knudson C líquido com a utilização de $128,42 \mathrm{~g} \mathrm{~L}^{-1}$ de polpa da banana nanica.

\section{REFERÊNCIAS}

ADELBERG JW; DESAMERO NV; HALE SA; YOUNG RE. 1997. Long term nutrient and water utilization during micropropagation of Cattleya on a liquid membrane sistem. Plant Cell and Tissue Organ Culture 48: 17.

ARAUJO AG. 2007. Micropropagação de Cattleya loddigesii 'tipo': fontes de nitrogênio, qualidade de luz, sacarose e ácido giberélico. Lavras: UFLA. 74p. (Tese doutorado)

ARAUJO AG; PASQUAL M; RODRIGUES VA; SILVA AB; SOARES GA. 2005. Concentração de $\mathrm{KNO}_{3}$ e $\mathrm{NH}_{4} \mathrm{NO}_{3}$ no crescimento in vitro de plântulas de orquídea. Plant Cell Culture and Micropropagation 1: 31-36.

ARAUJO AG; PASQUAL M; VILLA F; COSTA FC. 2006. Água de coco e polpa de banana no cultivo in vitro de plântulas de orquídea. Revista Ceres 53: 608-613.

ARAÚJO D. 2004. Cultivo de Orquídeas Cattleya, as mais belas orquídeas brasileiras. Revista Brasil Orquídeas 8: 18-26.

ARDITTI J; ERNST R. 1993. Micropropagation of orchids. New York: John Wiley, 682p.

CALDAS LS; HARIDASAN P; FERREIRA ME. 1998. Meios nutritivos. In: TORRES AC; CALDAS LS; BUSO JA. (eds). Cultura de tecidos e transformação genética de plantas. Brasília: Embrapa. p. 87-132. 
FARIA RT; DALIO RJD; UNEMOTO LK; SILVA GL. 2006. Propagação in vitro de Oncidium baueri Lindl. (Orchidaceae) sem uso de ágar. Acta Scientiarum Agronomy 28: 71-74.

GEORGE EF; HALL MA; DE KLERK GJ. 2008. Plant propagation by tissue culture. v.1 The Background, 3rd edition. Springer, Dordrecht, $501 \mathrm{p}$.

GRATTAPAGLIA D; MACHADO M. 1998. Micropropagação. In: TORRES AC; CALDAS LS; BUSO JA. (Ed.). Cultura de tecidos e transformação de plantas. Brasília:Embrapa, 183-260.

KNUDSON L. 1946. A new nutrient solution for the germination of orchid seed. American Orchid Society Bulletin 14: 214217.

MURASHIGE T; SKOOG FA. 1962. A revised medium for rapid growth and bio assays with tobacco tissue cultures. Physiologia Plantarum 15: 473-497.

NAGAO EO; PASQUAL M; RAMOS JD. 1994. Efeitos da sacarose e do nitrogênio inorgânico sobre a multiplicação in vitro de brotações de porta-enxerto de citros. Bragantia 53: 25-31.
PASQUAL M; CHALFUN NNJ: RAMOS JD. 2001. Cultura de tecidos: Tecnologia e aplicações: aplicação na propagação de plantas. Lavras: UFLA/FAEPE, $81 \mathrm{p}$.

PASQUAL M; SANTOS FC; FIGUEIREDO MA; JUNQUEIRA KP; REZENDE JC; FERREIRA EA. 2008. Micropropagação de abacaxizeiro ornamental. Horticultura Brasileira 26: 45-49.

SAS INSTITUTE. 1990. Statystical Analysis Sistem: Procedures guide: version 6. Cary, NC. 705p.

SATO AY; MARIA J; SEDIYAMA T; BORÉM A; CECON PR; JUNQUEIRA CS. 2001. Micropropagação da mandioca: influência da concentração de amônio com e sem BAP. Revista Ceres 48: 405-413.

SILVA ALL; FRANCO ETH; GESING JPA; PESSOA CC. 2002. Efeitos de alguns meios de cultura sobre o desenvolvimento in vitro de Cattleya tigrina A. Rich. Ex Beer Orchidaceae. ABCTP Notícias 4-7.
SILVA EF; PASQUAL M; PAIVA PDO; SILVA AB; NOGUEIRA DA. 2005. Polpa de banana e vitaminas do meio MS no cultivo in vitro de orquídea. Plant Cell Culture and Micropropagation 1: 8-12.

SONG MKR; SILVA GL; FARIA RT; TAKAHASHI LSA. 1999. Análise do crescimento e enraizamento in vitro de híbridos de Dendrobium nobile Lindl. (Orchidaceae) semeados em diferentes meios de cultura. In CONGRESSO BRASILEIRO DE FLORICULTURA E PLANTAS ORNAMENTAIS, 12., Anais... Jaboticabal:UNESP, p. 110.

TORRES AC; BARBOSA NVR. 2001. Condições de incubação para cultura in vitro. ABCTP Notícias 1-7.

TORRES AC; BARBOSA NVR; WILLADINO L; GUERRA MP; FERREIRA CF; PAIVA SAV. 2001. Meio e condições de incubação para cultura de tecidos de plantas. Brasília: Embrapa (Circular Técnica). 20p. 